\title{
Reactivity of $\left[\mathrm{Pt}\left(\mathrm{P}^{t} \mathrm{Bu}_{3}\right)_{2}\right]$ with Zinc(I/II) Compounds: Bimetallic Adducts, $\mathrm{Zn}-\mathrm{Zn}$ Bond Cleavage, and Cooperative Reactivity
}

\author{
Nereida Hidalgo, Carlos Romero-Pérez, Celia Maya, Israel Fernández, and Jesús Campos* \\ Cite This: Organometallics 2021, 40, 1113-1119 \\ Read Online
}

ABSTRACT: Metal-only Lewis pairs (MOLPs) based on zinc electrophiles are particularly interesting due to their relevance to Negishi cross-coupling reactions. Zinc-based ligands in bimetallic complexes also render unique reactivity to the transition metals at which they are bound. Here we explore the use of sterically hindered $\left[\mathrm{Pt}\left(\mathrm{P}^{t} \mathrm{Bu}_{3}\right)_{2}\right]$ (1) to access $\mathrm{Pt} / \mathrm{Zn}$ bimetallic complexes. Compounds $\left[\left(\mathrm{P}^{t} \mathrm{Bu}_{3}\right)_{2} \mathrm{Pt} \rightarrow \mathrm{Zn}\left(\mathrm{C}_{6} \mathrm{~F}_{5}\right)_{2}\right](2)$ and $\left[\mathrm{Pt}(\mathrm{ZnCp})_{6}\right]$ (3) $\left(\mathrm{Cp}^{*}=\right.$ pentamethylcyclopentadienyl) were isolated by reactions with $\mathrm{Zn}\left(\mathrm{C}_{6} \mathrm{~F}_{5}\right)_{2}$ and $\left[\mathrm{Zn}_{2} \mathrm{Cp}_{2}{ }_{2}\right]$, respectively. We also disclose the cooperative reactivity of $1 / \mathrm{ZnX}_{2}$ pairs $(\mathrm{X}=\mathrm{Cl}, \mathrm{Br}, \mathrm{I}$, and $\mathrm{OTf})$ toward water and dihydrogen, which can be understood in terms of bimetallic frustration.

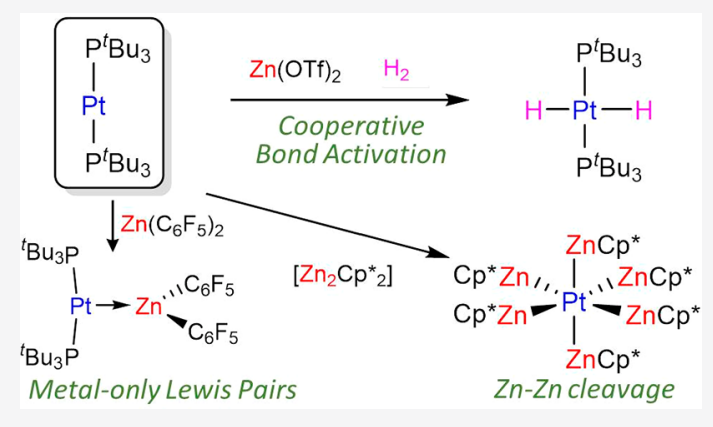

\section{INTRODUCTION}

The unique features of bimetallic complexes are behind the rapid development that has recently taken place in the field. ${ }^{1}$ Among these complexes, metal-only Lewis pairs (MOLPs), ${ }^{2}$ that is, bimetallic compounds in which the two metal atoms are held together exclusively by a dative $\mathrm{M} \rightarrow \mathrm{M}$ bond, constitute a fascinating family. MOLPs constructed around Lewis acidic zinc(II) fragments are particularly appealing due to their relevance to Negishi cross-coupling catalysis. In fact, intermediates containing dative $\mathrm{Pd} \rightarrow \mathrm{Zn}$ interactions are crucial to accessing low-energy transition states during transmetalation $^{3}$ and play essential roles in cis/trans isomerization $^{4}$ and deleterious homocoupling processes. ${ }^{5}$ Bergman and Tilley have shown that biaryl reductive elimination from $\mathrm{Pt}(\mathrm{II})$ compounds is accelerated upon $\mathrm{Zn}\left(\mathrm{C}_{6} \mathrm{~F}_{5}\right)_{2}$ coordination, ${ }^{6}$ while Whittlesey and Macgregor have explored a heterobimetallic $\mathrm{Ru} / \mathrm{Zn}$ compound and demonstrated that the unsaturated " $\mathrm{ZnMe}$ " terminus promotes $\mathrm{C}-\mathrm{H}$ reductive elimination and dihydrogen activation at the $\mathrm{Ru}(\mathrm{II})$ site. $^{7}$ Although Zn-based MOLPs remain rare $^{8}$ these findings highlight the opportunities that may emerge from combining zinc electrophiles with electron-rich transition metal compounds.

As for Lewis basic fragments, $\left[\mathrm{Pt}\left(\mathrm{PCy}_{3}\right)_{2}\right](\mathrm{Cy}=$ cyclohexyl $)$ is likely the most extensively investigated donor in MOLP chemistry. ${ }^{9}$ In fact, recently reported $\left[\left(\mathrm{PCy}_{3}\right)_{2} \mathrm{Pt} \rightarrow \mathrm{ZnBr}_{2}\right]$ is the first well-defined unsupported $\mathrm{M} \rightarrow \mathrm{Zn}$ (II) adduct. $^{10}$ Combination of the bulkier analogue $\left[\mathrm{Pt}\left(\mathrm{P}^{t} \mathrm{Bu}_{3}\right)_{2}\right](\mathbf{1})$ with a $\mathrm{Cu}(\mathrm{I})$ species revealed bimetallic cooperation during $\mathrm{O}-\mathrm{H}$ bond activation. ${ }^{11}$ Similarly, we have explored the reactivity of $\left[\left(\mathrm{P}^{t} \mathrm{Bu}_{3}\right)_{2} \mathrm{Pt} \rightarrow \mathrm{AgNTf}_{2}\right]\left(\mathrm{NTf}_{2}=\mathrm{bis}-\right.$ (trifluoromethanesulfonyl)imide), which readily cleaves $\mathrm{X}-\mathrm{H}$ $(\mathrm{X}=\mathrm{H}, \mathrm{C}, \mathrm{O}$, and $\mathrm{N})$ bonds across the $\mathrm{Pt}-\mathrm{Ag}$ linkage, while the parent monometallic components remain inactive. ${ }^{12}$ On these grounds, we decided to inspect the formation and reactivity of zinc-containing MOLPs based on $\left[\mathrm{Pt}\left(\mathrm{P}^{t} \mathrm{Bu}_{3}\right)_{2}\right]$ (1). In doing so, we have examined its reactivity with a range of zinc precursors, more precisely $\mathrm{ZnX}_{2}(\mathrm{X}=\mathrm{Cl}, \mathrm{Br}, \mathrm{I}$, and OTf; OTf = trifluoromethanesulfonate $), \mathrm{ZnR}_{2}(\mathrm{R}=\mathrm{Me}, \mathrm{Et}$, $\mathrm{Ph}, \eta^{5}-\mathrm{C}_{5} \mathrm{Me}_{5}$, and $\left.\mathrm{C}_{6} \mathrm{~F}_{5}\right)$, and the more exotic $\mathrm{Zn}(\mathrm{I})$ dimer $\left[\mathrm{Zn}_{2}\left(\eta^{5}-\mathrm{C}_{5} \mathrm{Me}_{5}\right)_{2}\right]\left(\mathrm{Zn}_{2} \mathrm{Cp}_{2}{ }_{2}\right) \cdot{ }^{13}$

\section{RESULTS AND DISCUSSION}

Treatment of $\left[\mathrm{Pt}\left(\mathrm{P}^{t} \mathrm{Bu}_{3}\right)_{2}\right]$ (1) with zinc (pseudo)halides in toluene did not offer any hint of adduct formation by NMR in the temperature range of -80 to $+70{ }^{\circ} \mathrm{C}$, which contrasts with the readily accessible $\left[\left(\mathrm{PCy}_{3}\right)_{2} \mathrm{Pt} \rightarrow \mathrm{ZnBr}_{2}\right] .{ }^{10}$ Considering that the basicity of 1 may be superior to that of $\left[\mathrm{Pt}\left(\mathrm{PCy}_{3}\right)_{2}\right]$, we ascribe the absence of MOLP formation from the former to steric reasons. Switching to dichloromethane, fluorobenzene, and tetrahydrofuran to improve the solubility of the zinc salt did not alter these results. However, addition of 1 equiv of the more acidic $\mathrm{Zn}\left(\mathrm{C}_{6} \mathrm{~F}_{5}\right)_{2}$ to a colorless $\mathrm{C}_{6} \mathrm{D}_{6}$ solution of $\mathbf{1}$ caused instant coloration to bright yellow. Multinuclear NMR spectroscopic analysis suggested formation of the bimetallic adduct $\left[\left(\mathrm{P}^{t} \mathrm{Bu}_{3}\right)_{2} \mathrm{Pt} \rightarrow \mathrm{Zn}\left(\mathrm{C}_{6} \mathrm{~F}_{5}\right)_{2}\right]$ ( 2 in Scheme 1$)$. The most distinctive feature is a pronounced decrease in the ${ }^{1} J_{\mathrm{PPt}}$ coupling constant to a value of $3328 \mathrm{~Hz}(\delta=93.1 \mathrm{ppm}$; c.f. 1: $\delta=100.2 \mathrm{ppm},{ }^{1} J_{\mathrm{PPt}}=4410 \mathrm{~Hz}$ ), a common symptom of

Received: February 12, 2021

Published: April 13, 2021 
Scheme 1. Reaction of $\left[\operatorname{Pt}\left(\mathrm{P}^{t} \mathrm{Bu}_{3}\right)_{2}\right]$ (1) with Zinc (Pseudo)halides and Organozinc Compounds ${ }^{a}$

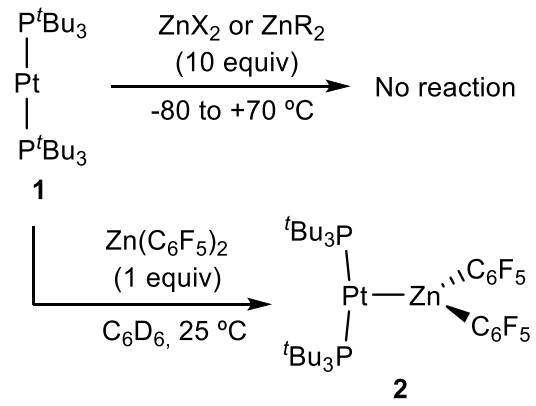

${ }^{a_{\text {Top: }}} \mathrm{X}=\mathrm{Cl}, \mathrm{Br}$, I, and OTf; $\mathrm{R}=\mathrm{Me}, \mathrm{Et}$, and $\mathrm{Ph}, \mathrm{C}_{5} \mathrm{Me}_{5}$; solvent $=$ $\mathrm{C}_{6} \mathrm{D}_{6}, \mathrm{CD}_{2} \mathrm{Cl}_{2}$, THF, or $\mathrm{C}_{6} \mathrm{H}_{5} \mathrm{~F}$.

MOLP formation in $\operatorname{Pt}(0)$ compounds due to the reduced $s$ character of the $\mathrm{Pt}-\mathrm{P}$ bonds in the bimetallic adduct. ${ }^{9,12}$ Alongside this, a new set of ${ }^{19} \mathrm{~F}\left\{{ }^{1} \mathrm{H}\right\}$ resonances at -115.7 , -157.4, and $-162.0 \mathrm{ppm}$ (c.f. $\mathrm{Zn}\left(\mathrm{C}_{6} \mathrm{~F}_{5}\right)_{2}: \delta=-118.0,-152.5$, and $-160.5 \mathrm{ppm})$ was recorded.

The molecular structure of $\mathbf{2}$ was authenticated by singlecrystal X-ray diffraction studies (Figure 1a) confirming the proposed bimetallic formulation. This represents the first example of a $\mathrm{Pt}(0)$ /organozinc MOLP. It exhibits a $\mathrm{T}$-shaped geometry around the platinum center, slightly distorted due to the steric pressure exerted by the tert-butyl groups in close proximity to the perfluorinated aryl rings $(\mathrm{P}-\mathrm{Pt}-\mathrm{P}=$
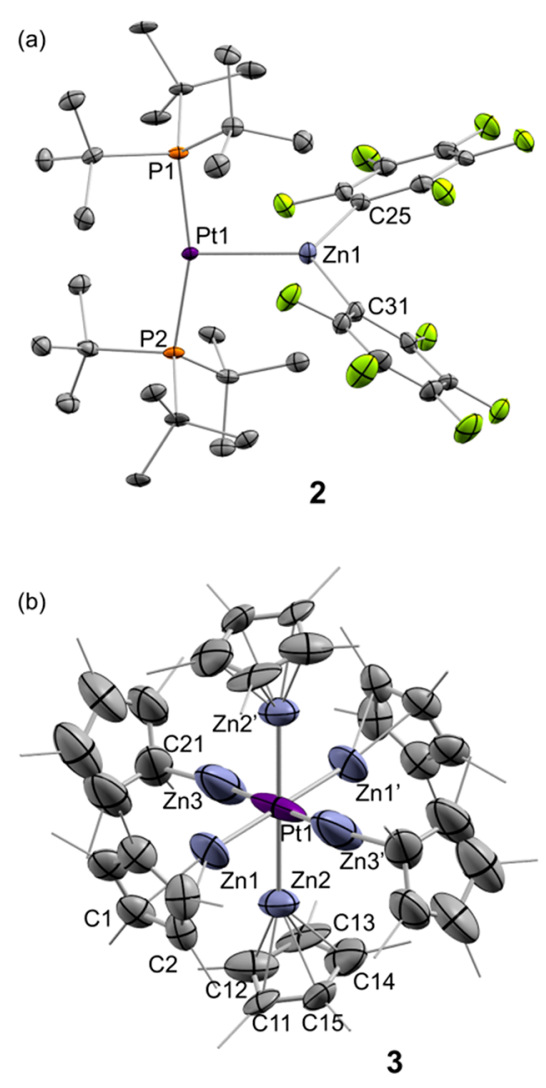

Figure 1. ORTEP diagram of compounds 2 and 3. Hydrogen atoms have been excluded, and methyl groups of $\mathrm{Cp}^{*}$ ligands are represented in wire-frame format for clarity. Thermal ellipsoids are set at $50 \%$ probability. $\left.165.32(4)^{\circ}\right)$. As in other bisphosphine $\mathrm{Pt}(0)$-based MOLPs, the $\mathrm{Pt}-\mathrm{P}$ bond distances (2.325 $\AA$ on average) are modestly elongated with respect to that of precursor $1(2.25 \AA) .{ }^{14}$ The $\mathrm{Pt}-\mathrm{Zn}$ bond length $(2.4663(6) \AA)$ is shorter than in the related [(phen) $\left.\mathrm{Ar}_{2} \mathrm{Pt}^{\mathrm{II}} \rightarrow \mathrm{Zn}\left(\mathrm{C}_{6} \mathrm{~F}_{5}\right)_{2}\right]$ (phen = phenanthroline) adduct, which contains a less basic $\mathrm{Pt}(\mathrm{II})$ donor $(2.5526(5) \AA){ }^{6}$ and just marginally longer than that in $\left[\left(\mathrm{Cy}_{3} \mathrm{P}\right)_{2} \mathrm{Pt} \rightarrow \mathrm{ZnBr}_{2}\right](2.4040(6) \AA) .{ }^{10}$ Steric constraints in 2 force the perfluorphenyl rings to bend away from the platinum center, with the $\mathrm{C} 25-\mathrm{Zn}-\mathrm{C} 31$ angle of $117.73(18)^{\circ}$ being significantly reduced compared to those of $\mathrm{Zn}\left(\mathrm{C}_{6} \mathrm{~F}_{5}\right)_{2}$ $\left(172.6^{\circ}\right)^{15}$ and even [(phen) $\left.\mathrm{Ar}_{2} \mathrm{Pt}^{\mathrm{II}} \rightarrow \mathrm{Zn}\left(\mathrm{C}_{6} \mathrm{~F}_{5}\right)_{2}\right]\left(134.8^{\circ}\right){ }^{6}$

At variance with its fluorinated analogue, the less acidic $\mathrm{ZnPh}_{2}$ does not react with $\mathbf{1}$, as monitored by variable temperature NMR and visually inferred by the colorless appearance of the reaction mixture even after prolonged periods of time. Similarly, no $\mathrm{Pt} \rightarrow \mathrm{Zn}$ interactions were detected upon addition of 10 equiv of $\mathrm{ZnR}_{2}(\mathrm{R}=\mathrm{Me}$, Et, and $\left.\eta^{5}-\mathrm{C}_{5} \mathrm{Me}_{5}\right)$ to $\mathrm{C}_{6} \mathrm{D}_{6}$ solutions of 1 , again pointing out the need for a highly electrophilic $\mathrm{Zn}$ center to overcome the distortion of the linear $\mathrm{Pt}(0)$ precursor to accommodate the bimetallic dative bond. Next, we examined the reactivity of 1 with the $\mathrm{Zn}(\mathrm{I})$ dimer $\left[\mathrm{Zn}_{2} \mathrm{Cp}_{2}{ }_{2}\right]^{13}$ in light of its capacity to form zincrich polymetallic complexes with transition metal precursors. ${ }^{16}$ For instance, Fischer has investigated the reactivity between $\left[\mathrm{Zn}_{2} \mathrm{Cp}_{2}{ }_{2}\right]$ and low-valent $\mathrm{M}(0)$ precursors $(\mathrm{M}=\mathrm{Ni}$, Pd, and $\mathrm{Pt})$, recurrently identifying the homolytic cleavage of the $\mathrm{Zn}-$ $\mathrm{Zn}$ bond by insertion of the transition metal. ${ }^{17}$

${ }^{31} \mathrm{P}\left\{{ }^{1} \mathrm{H}\right\}$ NMR monitoring of an equimolar mixture of $\mathbf{1}$ and $\left[\mathrm{Zn}_{2} \mathrm{Cp}_{2}{ }_{2}\right]$ in $\mathrm{C}_{6} \mathrm{D}_{6}$ showed the release of free phosphine $(\delta=$ $63.0 \mathrm{ppm})$ without any other detectable intermediate. It soon became evident that a 3 -fold excess of the $\mathrm{Zn}(\mathrm{I})$ dimer was required to achieve complete consumption of 1 . Under these conditions, the highly unstable compound $\left[\mathrm{Pt}\left(\mathrm{ZnCp}^{*}\right)_{6}\right]$ (3) forms as the major species (ca. $80 \%$ NMR yield) by insertion of the Pt center into the $\mathrm{Zn}-\mathrm{Zn}$ bonds of three molecules of $\left[\mathrm{Zn}_{2} \mathrm{Cp}_{2}{ }_{2}\right]$. (Scheme 2). Compound 3 slowly precipitates as

Scheme 2. Synthesis of Compound 3 by the Reaction between 1 and $\left[\mathrm{Zn}_{2} \mathrm{Cp}_{2}{ }_{2}\right]$

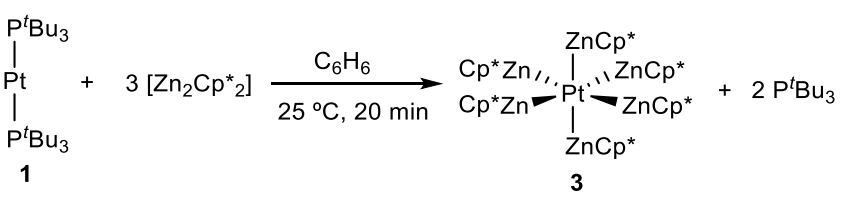

bright orange crystals, which allowed us to ascertain its heptametallic structure by X-ray diffraction analysis (Figure 1b). It can be described as an unusual 16-electron octahedral complex in which each vertex is occupied by a neutral 1electron $\mathrm{ZnCp} *$ ligand. This is in stark contrast with all prior Zn-rich polymetallic compounds of late transition metals, which consistently fulfill the 18 valence electron rule. ${ }^{16}$ The steric shrouding provided by the six planar cyclopentadienyl ligands stabilizes the somewhat encapsulated electron-rich platinum center.

The solid-state structure shows three pairs of $\mathrm{ZnCp}$ * ligands that differ slightly from each other in terms of $\mathrm{Zn}$ coordination. Two of these fragments present $\eta^{5}$-coordination $\left(d_{\mathrm{Zn}-\mathrm{C}} \approx\right.$ 2.24-2.37 $\AA$ ), and a second pair binds to the $C \mathrm{p}^{*}$ in an $\eta^{2}$ fashion. The third pair exhibits an $\eta^{1}$-binding (shortest $d_{\mathrm{Zn} 3-\mathrm{C} 21}$ $=2.06(3) \AA$; the rest are $>2.6 \AA$ ). While the former two pairs 
present $\mathrm{Pt}-\mathrm{Zn}$ bond distances $(2.419(3)$ and $2.401(4) \AA$ ) comparable to prior examples, ${ }^{17}$ the $\eta^{1}$-bound $\mathrm{ZnCp}$ * fragment displays a $\mathrm{Pt}-\mathrm{Zn}$ bond $(2.238(7) \AA ̊$ ) shortened by $0.34 \AA$ with respect to the sum of the covalent radii $(2.58 \AA){ }^{18}$ In THF- $d_{8}$ solution, a single ${ }^{1} \mathrm{H}$ NMR resonance at $1.92 \mathrm{ppm}$ indicates rapid dynamic exchange among the possible conformations of the $\mathrm{ZnCp} *$ ligands. In fact, low temperature NMR (up to $-80{ }^{\circ} \mathrm{C}$ ) was insufficient to freeze the dynamic process.

Compound 3 strongly resembles the closed-shell 18-electron $\left[\mathrm{Pt}(\mathrm{ZnCp})_{4}(\mathrm{ZnR})_{4}\right]$ species $(\mathrm{R}=\mathrm{Me}$ and $\mathrm{Et})$ described by Fischer and co-workers. ${ }^{17 \mathrm{~b}}$ The latter compounds exhibit rather long $\mathrm{Zn} \cdots \mathrm{Zn}$ distances (ranging from 2.812 to $3.115 \AA$ ), which have been regarded as noninteracting or only weakly interacting. ${ }^{17 \mathrm{e}}$ Similar $\mathrm{Zn} \cdots \mathrm{Zn}$ distances were found in 3 (>3.0 $\AA$ ). To confirm the negligible interaction between the zinc centers in 3, we computationally explored the topology of the model system $\mathrm{Pt}(\mathrm{ZnH})_{6}$, analogous to the model $\mathrm{Pt}(\mathrm{ZnH})_{8}$ used by Fischer and Frenking to understand the bonding situation in $\left.\left[\mathrm{Pt}(\mathrm{ZnCp} *)_{4}(\mathrm{ZnR})_{4}\right]\right]^{17 \mathrm{~b}, \mathrm{e}}$ using the QTAIM (Quantum Theory of Atoms in Molecules) method (see computational details in the Supporting Information). Figure 2

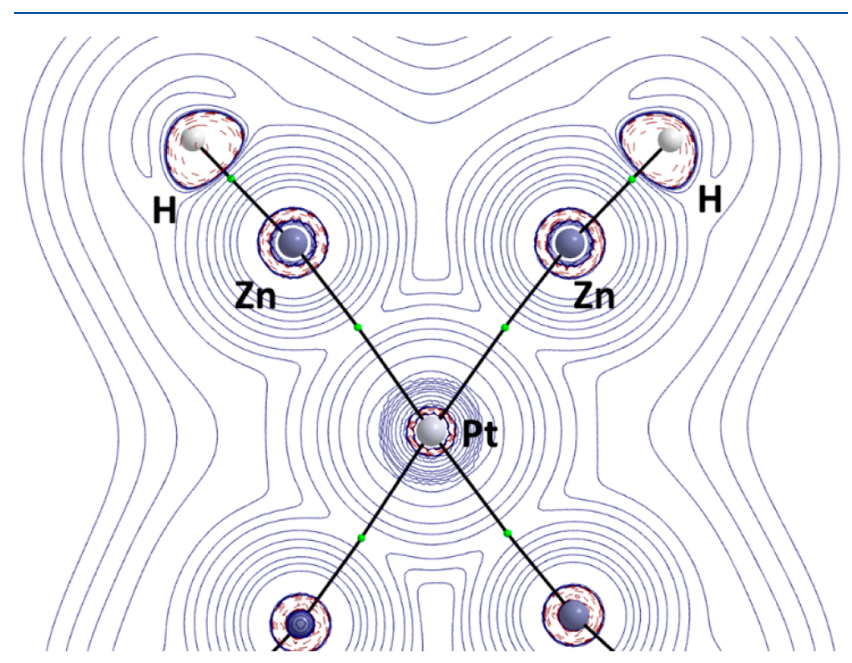

Figure 2. Contour line diagrams $\nabla^{2} \rho(\mathrm{r})$ for $\mathrm{Pt}(\mathrm{ZnH})_{6}$ in the $\mathrm{Zn}-\mathrm{Pt}-$ $\mathrm{Zn}$ plane. The solid lines connecting the atomic nuclei are the bond paths, while the small green spheres indicate the corresponding bond critical points.

shows the Laplacian distribution of $\mathrm{Pt}(\mathrm{ZnH})_{6}$ computed in the $\mathrm{Zn}-\mathrm{Pt}-\mathrm{Zn}$ plane. As expected, bond critical points (BCPs) together with their associated bond paths (BPs) are found between the zinc and platinum centers (computed $\mathrm{Pt}-\mathrm{Zn}$ bond distances $\sim 2.47 \AA$ ). In contrast, no BCPs or BPs were located between the zinc atoms (computed $\mathrm{Zn} \cdots \mathrm{Zn}$ bond distances ranging from 2.91 to $2.93 \AA$ ), which similar to $\mathrm{Pt}(\mathrm{ZnR})_{8}{ }^{17 \mathrm{~b}, \mathrm{e}}$ supports the above-commented noninteracting nature of $\mathrm{Zn} \cdots \mathrm{Zn}$ in 3 .

More quantitative insight into the bonding situation in 3 can be obtained by means of the energy decomposition analysis (EDA) method, also used by Fischer, Frenking, and co-workers to analyze the bonding in the analogous $\mathrm{Pt}(\mathrm{ZnH})_{8}\left(D_{4 d}\right){ }^{17 \mathrm{~b}}$ Thus, we compare the EDA data for $\mathrm{Pt}(\mathrm{ZnH})_{6}$ and $\mathrm{Pt}(\mathrm{ZnH})_{8}$ using the same partitioning scheme reported previously, namely, $\operatorname{Pt}(0)$ and $(\mathrm{ZnH})_{n}(n=6$ and 8$)$ in their singlet states as fragments. Table 1 gathers the corresponding EDA values computed at the ZORA-BP86-D3/TZ2P//BP86-D3/
Table 1. EDA results at ZORA-BP86-D3/TZ2P for $\left[\mathrm{Pt}(\mathrm{ZnH})_{n}\right](n=6$ and 8$)$ with the fragments $\mathrm{M}\left(\mathrm{s}^{0} \mathrm{~d}^{10}\right)$ and $(\mathrm{ZnH})_{n}$ in the Singlet State

\begin{tabular}{clll} 
compound & \multicolumn{1}{c}{$\mathrm{Pt}(\mathrm{ZnH})_{6}$} & \multicolumn{1}{c}{$\mathrm{Pt}(\mathrm{ZnH})_{8}$} & \multicolumn{1}{c}{$\mathrm{Pt}(\mathrm{ZnH})_{8}{ }^{a}$} \\
$\Delta E_{\text {int }}$ & -234.1 & -288.9 & -279.0 \\
$\Delta E_{\text {Pauli }}$ & 434.7 & 468.8 & 486.0 \\
$\Delta E_{\text {elstat }}{ }^{a}$ & $-518.4(77.5 \%)$ & $-575.6(76.0 \%)$ & $-583.4(76.3 \%)$ \\
$\Delta E_{\text {orb }}{ }^{b}$ & $-145.5(21.8 \%)$ & $-175.2(23.1 \%)$ & $-181.6(23.7 \%)$ \\
$\Delta E_{\text {disp }}{ }^{b}$ & $-4.8(0.7 \%)$ & $-6.9(0.9 \%)$ & \\
$q(\mathrm{Pt})^{c}$ & -0.21 & -0.21 &
\end{tabular}

${ }^{a}$ Energy values $(\mathrm{kcal} / \mathrm{mol})$ taken from ref $17 \mathrm{~b} .{ }^{b}$ Percentage values in parentheses give the contributions to the total attractive energy $\Delta E_{\text {elstat }}+\Delta E_{\text {orb }}+\Delta E_{\text {disp. }}{ }^{c}$ Computed Hirshfeld charges at the platinum center.

def2-TZVPP level including the original data reported previously for $\mathrm{Pt}(\mathrm{ZnH})_{8}\left(D_{4 d}\right)$ computed at the rather similar ZORA-BP86/TZ2P//RI-BP86/def2-TZVPP level. From the data in Table 1 , the resemblance between both $\operatorname{Pt}(0)$ compounds becomes evident. Although the computed interaction energy, $\Delta E_{\text {int }}$ is higher in $\mathrm{Pt}(\mathrm{ZnH})_{8}$ (which is not surprising as the $\mathrm{Pt}$ center interacts with two additional one-electron $\mathrm{ZnH}$ ligands), in both cases, the platinum atom bears a small negative charge, which is consistent with the chosen neutral fragments. Despite that, the main contribution to the bonding comes from the electrostatic interactions, representing ca. $76-77 \%$ of the total attractions. The contribution resulting from orbital interactions (mainly involving the $\mathrm{d}$ atomic orbitals of platinum) is significantly much lower and those coming from dispersion interactions can be considered as negligible. This therefore indicates that the bonding in newly prepared compound 3 (and the analogous $\left.\left[\mathrm{Pt}(\mathrm{ZnCp} *)_{4}(\mathrm{ZnR})_{4}\right]\right)$ can be viewed mainly as a result of the electrostatic interactions between the platinum center and the surrounding $\mathrm{ZnCp} *$ ligands.

We next interrogated the ability of these $\mathrm{Pt} / \mathrm{Zn}$ bimetallic pairs to activate both polar and nonpolar bonds using water and dihydrogen as model substrates. We mainly directed our efforts toward pairs containing inorganic zinc salts, as organozinc compounds $\left(1 / \mathrm{ZnR}_{2}, 2\right.$ and 3$)$ were rapidly hydrolyzed in the presence of water. Besides, those species remained inactive toward $\mathrm{H}_{2}$ under all attempted conditions. In contrast, equimolar benzene suspensions of 1 and $\mathrm{ZnX}_{2}$ (X $=\mathrm{Cl}, \mathrm{Br}, \mathrm{I}$, and OTf) readily react with $\mathrm{H}_{2} \mathrm{O}$ ( 5 equiv) by means of $\mathrm{O}-\mathrm{H}$ bond activation (Scheme 3). ${ }^{11,12}$ It is

Scheme 3. Activation of Polar O-H Bond by $\mathrm{Pt}(0) / \mathrm{Zn}(\mathrm{II})$ FLPs

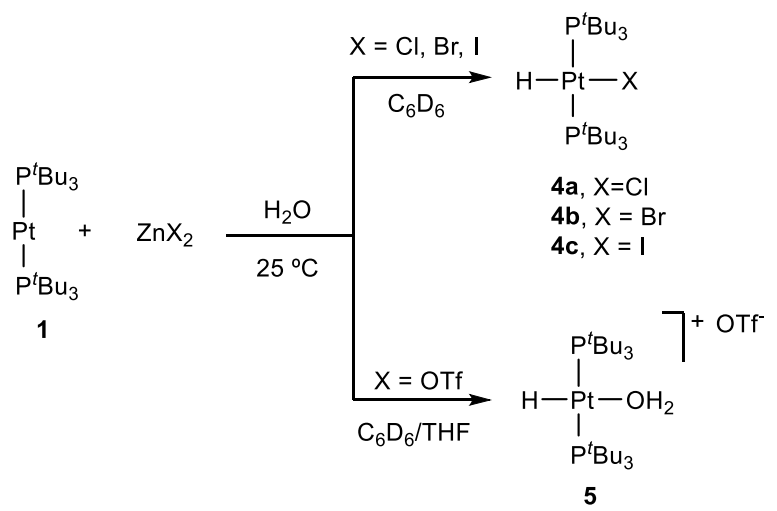


important to remark that $\mathbf{1}$ does not react with water on its own even under more forcing conditions $\left(80{ }^{\circ} \mathrm{C}, 24 \mathrm{~h}\right)$. However, in the presence of zinc halides formation of trans$\left[\mathrm{PtHX}\left(\mathrm{P}^{t} \mathrm{Bu}_{3}\right)_{2}\right](\mathrm{X}=\mathrm{Cl}, \mathrm{Br}$, and $\mathrm{I} ; 4$, Scheme 3$)$ is evidenced by a distinctive low-frequency ${ }^{1} \mathrm{H}$ NMR resonance due to the metal hydride $(\delta=-19.2(4 \mathrm{a}, \mathrm{Cl}),-18.4(4 \mathrm{~b}, \mathrm{Br})$, and -16.4 (4c, I) ppm), exhibiting scalar coupling to both ${ }^{31} \mathrm{P}\left({ }^{2} J_{\mathrm{HP}} \approx 12\right.$ $\mathrm{Hz})$ and ${ }^{195} \mathrm{Pt}\left({ }^{1} J_{\mathrm{HPt}} \approx 1100 \mathrm{~Hz}\right)$ nuclei. In the case of $\mathrm{Zn}(\mathrm{OTf})_{2}$, the reduced coordinating capacity of the triflate moiety compared to halide anions led to the cationic hydrideaquo complex trans- $\left[\mathrm{PtH}\left(\mathrm{OH}_{2}\right)\left(\mathrm{P}^{t} \mathrm{Bu}_{3}\right)_{2}\right]^{+}(5)$ as the only observable product. Formation of compounds 4 and 5 is accompanied by the appearance of a fine precipitate of zinc hydroxide salts.

As mentioned briefly above, water activation by combining 1 with transition metal Lewis acids $\left[\mathrm{Cu}\left(\mathrm{CH}_{3} \mathrm{CN}\right)_{4}\right] \mathrm{PF}_{6}{ }^{11}$ and $\mathrm{AgNTf}_{2}{ }^{12}$ has recently been reported. Formation of an intermediate characterized by a $\mathrm{Pt} \rightarrow \mathrm{M}$ dative interaction is proposed as the initial step in both cases, after which the cooperative cleavage of the $\mathrm{O}-\mathrm{H}$ bond takes place. Our experiments indicate that bimetallic adduct formation is not favored for zinc salts; thus, an FLP-type mechanism seems more likely. In fact, we have already demonstrated that compound 1 acts as a Lewis basic site in bimetallic FLPs by partnering it with sterically crowded $\mathrm{Au}(\mathrm{I})$ compounds. ${ }^{19}$ Our prior mechanistic investigations allowed us to conclude that those $\mathrm{Pt}(0) / \mathrm{Au}(\mathrm{I})$ pairs mediate the cleavage of the $\mathrm{H}-\mathrm{H}$ bond in dihydrogen by a genuine FLP mechanism. ${ }^{19 b}$ We wondered if the same would apply for the $\mathrm{Pt} / \mathrm{Zn}$ pairs investigated herein. Once again, it is worth mentioning that neither 1 nor zinc (pseudo)halides react with $\mathrm{H}_{2}$ on their own (Scheme 4a). Similarly, the combination of $\mathbf{1}$ and zinc halides

Scheme 4. Reactivity of Bimetallic Pair $1 / \mathrm{Zn}(\mathrm{OTf})_{2}$ with $\mathrm{H}_{2}$

(a)

$$
1 \underset{70{ }^{\circ} \mathrm{C}, \mathrm{C}_{6} \mathrm{H}_{6}}{\stackrel{\mathrm{H}_{2}(1 \mathrm{bar})}{\longrightarrow}} \text { No reaction }
$$

(b)

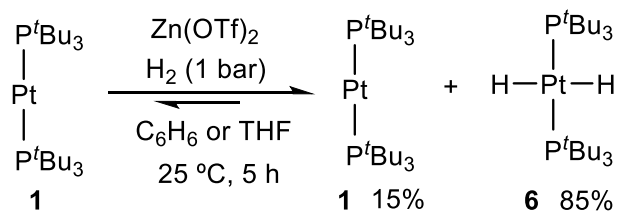

(c)

$$
\begin{aligned}
& 6 \underset{\begin{array}{c}
\mathrm{THF}-d_{8} / \mathrm{C}_{6} \mathrm{D}_{6}(2: 1), \\
25^{\circ} \mathrm{C}, 5 \mathrm{~h}
\end{array}}{\stackrel{\mathrm{Zn}(\mathrm{OTf})_{2}(10 \mathrm{~mol} \%)}{\longrightarrow}} \quad \begin{array}{c}
\mathbf{6} \\
\mathbf{\mathrm { N }}
\end{array}
\end{aligned}
$$

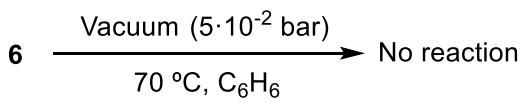

in benzene or THF did not provide any reactivity upon exposure to $\mathrm{H}_{2}\left(2 \mathrm{bar}, 70{ }^{\circ} \mathrm{C}\right)$. However, in the presence of the more acidic $\mathrm{Zn}(\mathrm{OTf})_{2}$, dihydrogen activation proceeds smoothly to generate $\mathrm{Pt}(\mathrm{II})$ dihydride $6^{20}$ even under mild conditions $\left(\mathrm{H}_{2} 1 \mathrm{bar}, 25{ }^{\circ} \mathrm{C}, 5 \mathrm{~h}\right.$; Scheme $\left.4 \mathrm{~b}\right)$. Compound 6 is produced in ca. $85 \%$ spectroscopic yield, exhibiting a characteristic ${ }^{1} \mathrm{H}$ NMR resonance at $-2.91 \mathrm{ppm}\left({ }^{2} J_{\mathrm{HP}}=16.4\right.$ $\left.\mathrm{Hz},{ }^{1} J_{\mathrm{HPt}}=780.6 \mathrm{~Hz}\right)$.
Formation of 6 suggests a catalytic role of $\mathrm{Zn}(\mathrm{OTf})_{2}$ during the hydrogenation of $\mathbf{1}$, which has previously been observed for the hydrogenation of imines catalyzed by the same zinc species. $^{21}$ In fact, decreasing the amount of $\mathrm{Zn}(\mathrm{OTf})_{2}$ to only 5 mol \% with respect to 1 under otherwise identical conditions led to the formation of $\mathbf{6}$ in comparable yields. In fact, the amount of zinc and the nature of the solvent did not have any apparent influence on the extent of dihydride produced, which was obtained in yields between 80 and 90\% in all cases. Attempts to reach full hydrogenation of 1 were unsuccessful despite longer reaction times, higher temperatures and increasing loadings of zinc. These observations imply that hydrogenation of $\mathbf{1}$ is a reversible process. We confirmed this idea by adding $\mathrm{Zn}(\mathrm{OTf})_{2}(10 \mathrm{~mol} \%)$ to a THF- $d_{8} / \mathrm{C}_{6} \mathrm{D}_{6}(2: 1)$ solution of dihydride 6 in a sealed NMR tube (Scheme $4 \mathrm{c}$ ). Reaction monitoring evidenced evolution to a mixture of both $\mathbf{1}$ and $\mathbf{6}$ in a ca. 2:3 ratio after $5 \mathrm{~h}$, as well a minute amount of free $\mathrm{H}_{2}$ identified by an ${ }^{1} \mathrm{H}$ NMR peak at $4.42 \mathrm{ppm}$. Replacing the atmosphere by $\mathrm{H}_{2}$ ( 1 bar) led to 6 in around $85 \%$ yield. The presence of zinc is also essential for dehydrogenation, since in its absence the release of $\mathrm{H}_{2}$ could not be detected even by heating 6 under dynamic vacuum $\left(70{ }^{\circ} \mathrm{C}, 50 \cdot \mathrm{mbar}\right.$, Scheme $4 \mathrm{~d})$. This process resembles both the dehydrogenation of $\left[\mathrm{PtH}_{2}\left(\mathrm{PCy}_{3}\right)_{2}\right]$ promoted by $\mathrm{C}_{60},{ }^{22}$ as well as the role played by $\mathrm{Zn}\left(\mathrm{C}_{6} \mathrm{~F}_{5}\right)_{2}$ in facilitating biaryl reductive elimination from $\mathrm{Zn}(\mathrm{II})$ complexes. $^{6}$

The mechanism of reversible heterolytic dihydrogen splitting holds great interest due to its connection to hydrogen production and the action of hydrogenase enzymes. It has also been largely studied as a benchmark transformation to gauge FLP behavior and, despite its apparent simplicity, remains a topic of intense research. ${ }^{23}$ In this line, the absence of adduct formation from the pair $1 / \mathrm{Zn}(\mathrm{OTf})_{2}$ along with its cooperative bond activation could be understood in terms of FLP principles. ${ }^{24}$ We performed several experiments to gain some preliminary mechanistic information. First, we determined the kinetic isotopic effect (KIE) for $\mathrm{H}_{2}$ versus $\mathrm{D}_{2}$ splitting, which has a strong inverse value of $0.59 \pm 0.1$ (see the Supporting Information for details). This is an uncommon finding ${ }^{25}$ that compares well with our previously reported $\mathrm{Pt}(0) / \mathrm{Au}(\mathrm{I})$ bimetallic FLP $(\mathrm{KIE}=0.46 \pm 0.04)$, where a genuine frustrated mechanism was ascertained. ${ }^{19 b}$ We postulated that the origin for such a strong inverse KIE derived from an FLP productlike transition state whose bimetallic structure offered an assortment of $\mathrm{H}$-containing bending modes that contribute to the zero-point energy (ZPE). We anticipate that a similar transition state in the present system (B in Scheme 5) would analogously derive in a strong inverse KIE, as observed experimentally. Direct oxidative addition of dihydrogen over $\mathbf{1}$ to form cis- $\left[\mathrm{PtH}_{2}\left(\mathrm{P}^{t} \mathrm{Bu}_{3}\right)_{2}\right]$ followed by $\mathrm{Zn}$-assisted isomerization ${ }^{4}$ could be considered an alternative mechanism ( $\mathbf{C}$ in Scheme 5). However, solutions of $1 / \mathrm{Zn}(\mathrm{OTf})_{2}$ catalyze rapid $\left(t_{1 / 2}<15 \mathrm{~min}\right)$ exchange between $\mathrm{H}_{2}$ and $\mathrm{D}_{2}$ to produce $\mathrm{HD}$ $\left(\delta=4.36 \mathrm{ppm},{ }^{1} J_{\mathrm{HD}}=42.6 \mathrm{~Hz}\right)$ in a statistical amount, which seems to disfavor a classical oxidative addition route. In fact, the individual monometallic species mediate the exchange at a considerable slower pace $\left(t_{1 / 2}>2\right.$ days $)$. Interestingly, compound $\left[\mathrm{PtH}\left(\mathrm{P}^{t} \mathrm{Bu}_{3}\right)_{2}\right]^{+}$, which would be an intermediate during FLP-type $\mathrm{H}_{2}$ activation, promotes $\mathrm{H} / \mathrm{D}$ scrambling at a rate comparable to the bimetallic pair. This agrees with its existence as a transient intermediate during the hydrogenation of 1, thus supporting the idea of a bimetallic FLP mechanism (through $\mathbf{B}$ in Scheme 5). Nevertheless, these preliminary 
Scheme 5. Potential Mechanisms for $\mathrm{H}_{2}$ Activation by 1 / $\mathrm{Zn}(\mathrm{OTf})_{2}$

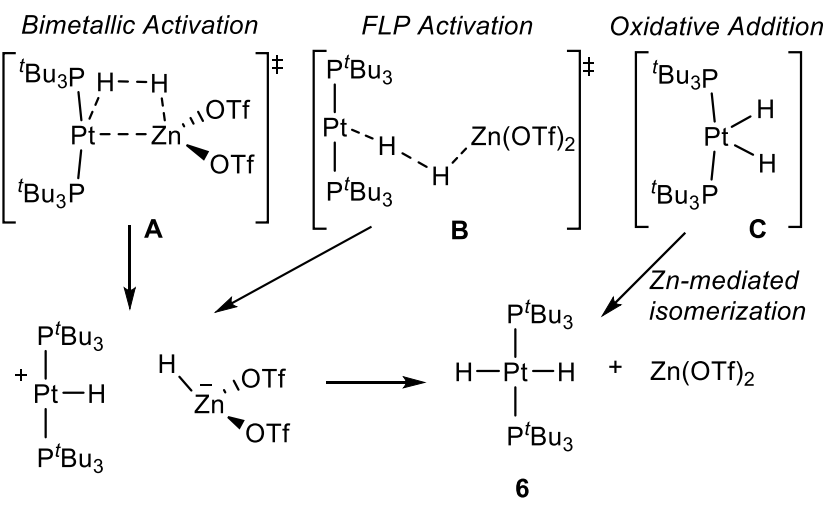

experiments cannot yet rule out a more traditional bimetallic $\mathrm{H}_{2}$ activation route implying a transient dative $\mathrm{Pt} \rightarrow \mathrm{Zn}$ bond (A in Scheme 5) or the active participation of triflate substituents. $^{26}$

ConclusionsIn summary, we report the formation of two new $\mathrm{Pt} / \mathrm{Zn}$ polymetallic complexes. While the metal-only Lewis adduct $\left[\left(\mathrm{P}^{t} \mathrm{Bu}_{3}\right)_{2} \mathrm{Pt} \rightarrow \mathrm{Zn}\left(\mathrm{C}_{6} \mathrm{~F}_{5}\right)_{2}\right]$ (2) represents the first $\mathrm{Pt}(0)$ /organozinc MOLP, the reaction between $[\mathrm{Pt}$ $\left.\left(\mathrm{P}^{t} \mathrm{Bu}_{3}\right)_{2}\right] \quad(\mathbf{1})$ and $\left[\mathrm{Zn}_{2} \mathrm{Cp}_{2}{ }_{2}\right]$ yields the hexametallic, homoleptic compound $\left[\mathrm{Pt}\left(\mathrm{ZnCp}^{*}\right)_{6}\right]$ (3). At variance with previous $\mathrm{Zn}$-rich polymetallic compounds, the latter does not fulfill the 18 valence electron rule, since it is considered an octahedral 16-electron species. While these complexes remain inactive toward dihydrogen, pairing 1 with $\mathrm{Zn}(\mathrm{OTf})_{2}$ results in cooperative dihydrogen cleavage. Preliminary kinetic and isotopic exchange experiments support a bimetallic FLP-type mechanism. Similarly, the activation of $\mathrm{O}-\mathrm{H}$ bonds in water proceeds readily in the presence of $\mathrm{Pt} / \mathrm{Zn}$ pairs, while the individual components reveal no activity.

\section{EXPERIMENTAL SECTION}

General Considerations. All preparations and manipulations were carried out using standard Schlenk and glovebox techniques, under an atmosphere of argon and of high purity nitrogen, respectively. All solvents were dried, stored over $3 \AA$ molecular sieves, and degassed prior to use. Toluene $\left(\mathrm{C}_{7} \mathrm{H}_{8}\right)$ and n-pentane $\left(\mathrm{C}_{5} \mathrm{H}_{12}\right)$ were distilled under nitrogen over sodium. Tetrahydrofuran (THF) and diethyl ether were distilled under nitrogen over sodium/ benzophenone. $\left(D_{6}\right)$ Benzene was dried over molecular sieves $(3 \AA)$, and $\left(D_{8}\right)$ THF was distilled under argon over sodium/benzophenone, and $\mathrm{CD}_{2} \mathrm{Cl}_{2}$ and fluorobenzene over $\mathrm{CaH}_{2}$ distilled under argon. Compounds $1,{ }^{27} \mathrm{ZnPh}_{2},{ }^{28}\left[\mathrm{Zn}_{2} \mathrm{Cp}_{2}{ }_{2}\right],{ }^{29}$ and $\left[\mathrm{PtHCl}\left(\mathrm{PtBu}_{3}\right)_{2}\right]^{30}$ were prepared as described previously. Other chemicals were commercially available and used as received. Solution NMR spectra were recorded on Bruker AMX-300, DRX-400 and DRX-500 spectrometers. Spectra were referenced to external $\mathrm{SiMe}_{4}(\delta: 0 \mathrm{ppm})$ using the residual proton solvent peaks as internal standards ( ${ }^{1} \mathrm{H}$ NMR experiments) or the characteristic resonances of the solvent nuclei $\left({ }^{13} \mathrm{C} N M R\right.$ experiments), while ${ }^{31} \mathrm{P}$ was referenced to $\mathrm{H}_{3} \mathrm{PO}_{4}$ and ${ }^{19} \mathrm{~F}$ to $\mathrm{CFCl}_{3}$. Spectral assignments were made by routine one- and two-dimensional NMR experiments where appropriate. For elemental analyses, a LECO TruSpec CHN elementary analyzer was utilized. The supplementary crystallographic data for this paper has been deposited in the Cambridge Crystallographic Data Centre with codes 2062801 and 2062802.

Compound 2. To a mixture of $\left[\mathrm{Pt}\left(\mathrm{P}^{t} \mathrm{Bu}_{3}\right)_{2}\right]$ (1) (50 mg, 0.083 $\mathrm{mmol})$ and $\mathrm{Zn}\left(\mathrm{C}_{6} \mathrm{~F}_{5}\right)_{2}(33 \mathrm{mg}, 0.083 \mathrm{mmol})$ was added $5 \mathrm{~mL}$ of toluene, and the solution was stirred for $30 \mathrm{~min}$, then kept at $-30^{\circ} \mathrm{C}$. Orange crystals of 2 were collected and washed with cold pentane (43 mg, 52\%). Anal. Calcd for $\mathrm{C}_{36} \mathrm{H}_{54} \mathrm{~F}_{10} \mathrm{P}_{2} \mathrm{PtZn}$ : C, 43.3; H, 5.5. Found: C, 43.0; H, 5.7. ${ }^{1} \mathrm{H}$ NMR $\left(400 \mathrm{MHz}, \mathrm{C}_{6} \mathrm{D}_{6}, 25{ }^{\circ} \mathrm{C}\right) \delta: 1.28$ (vt, $54 \mathrm{H}$, $\left.{ }^{3} J_{\mathrm{HP}}=6.3 \mathrm{~Hz},{ }^{\mathrm{t}} \mathrm{Bu}\right) \cdot{ }^{13} \mathrm{C}\left\{{ }^{1} \mathrm{H}\right\} \mathrm{NMR}\left(100 \mathrm{MHz}, \mathrm{CD}_{2} \mathrm{Cl}_{2}, 25{ }^{\circ} \mathrm{C}\right) \delta$ : $148.6\left(\mathrm{br} \mathrm{d},{ }^{1} J_{\mathrm{CF}}=227 \mathrm{~Hz}, o-\mathrm{C}_{6} \mathrm{~F}_{5}\right), 139.8\left(\mathrm{br} \mathrm{d},{ }^{1} J_{\mathrm{CF}}=232 \mathrm{~Hz}, p-\right.$ $\left.\mathrm{C}_{6} \mathrm{~F}_{5}\right), 136.6\left(\mathrm{br} \mathrm{d},{ }^{1} J_{\mathrm{CF}}=254 \mathrm{~Hz}, m-\mathrm{C}_{6} \mathrm{~F}_{5}\right), 128.2\left(\mathrm{br}\right.$, ipso- $\left.\mathrm{C}_{6} \mathrm{~F}_{5}\right)$, $40.2\left(\mathrm{vt},{ }^{1} J_{\mathrm{CP}}=8 \mathrm{~Hz}, \mathrm{Pt}-\mathrm{P}\left(\mathrm{C}\left(\mathrm{CH}_{3}\right)_{3}\right), 33.0\left(\mathrm{Pt}-\mathrm{P}\left(\mathrm{C}\left(\mathrm{CH}_{3}\right)_{3}\right)\right.\right.$. ${ }^{31} \mathrm{P}\left\{{ }^{1} \mathrm{H}\right\} \operatorname{NMR}\left(160 \mathrm{MHz}, \mathrm{C}_{6} \mathrm{D}_{6}, 25{ }^{\circ} \mathrm{C}\right) \delta: 93.1\left({ }^{1} J_{\mathrm{PPt}}=3328 \mathrm{~Hz}\right)$. ${ }^{19} \mathrm{~F}\left\{{ }^{1} \mathrm{H}\right\}$ NMR $\left(376 \mathrm{MHz}, \mathrm{C}_{6} \mathrm{D}_{6}, 25{ }^{\circ} \mathrm{C}\right) \delta:-115.7,-157.4,-162.0$.

Compound 3. To a mixture of complex $\left[\mathrm{Pt}\left(\mathrm{P}^{t} \mathrm{Bu}_{3}\right)_{2}\right](\mathbf{1})(50 \mathrm{mg}$, $0.083 \mathrm{mmol})$ and $\left[\mathrm{Zn}_{2} \mathrm{Cp}_{2}{ }_{2}\right](99 \mathrm{mg}, 0.249 \mathrm{mmol})$ was added $3 \mathrm{~mL}$ of benzene. The solution was stirred for $20 \mathrm{~min}$ at room temperature. Complex 3 crystallized from the crude reaction after $12 \mathrm{~h}(34 \mathrm{mg}$, $30 \%)$. Anal. Calcd for $\mathrm{C}_{60} \mathrm{H}_{90} \mathrm{PtZn}_{6}: \mathrm{C}, 51.5 ; \mathrm{H}, 6.5$. Found: $\mathrm{C}, 51.5$; $\mathrm{H}$, 6.8. ${ }^{1} \mathrm{H}$ NMR $\left(400 \mathrm{MHz}, \mathrm{C}_{6} \mathrm{D}_{6}, 25{ }^{\circ} \mathrm{C}\right) \delta: 1.45(\mathrm{Me}) .{ }^{13} \mathrm{C}\left\{{ }^{1} \mathrm{H}\right\}$ NMR $\left(100 \mathrm{MHz}, \mathrm{THF}-d_{8}, 25^{\circ} \mathrm{C}\right) \delta: 112.0\left(\mathrm{C}_{5} \mathrm{Me}_{5}\right), 12.0\left(\mathrm{C}_{5} M e_{5}\right)$.

\section{ASSOCIATED CONTENT}

\section{Supporting Information}

The Supporting Information is available free of charge at https://pubs.acs.org/doi/10.1021/acs.organomet.1c00088.

Synthetic procedures, kinetic studies, X-ray structural data, computational details, and NMR spectra (PDF)

Cartesian coordinates (XYZ)

\section{Accession Codes}

CCDC 2062801 and 2062802 contain the supplementary crystallographic data for this paper. These data can be obtained free of charge via www.ccdc.cam.ac.uk/data_request/cif, or by emailing data_request@ccdc.cam.ac.uk, or by contacting The Cambridge Crystallographic Data Centre, 12 Union Road, Cambridge CB2 1EZ, UK; fax: +44 1223336033.

\section{AUTHOR INFORMATION}

\section{Corresponding Author}

Jesús Campos - Instituto de Investigaciones Químicas (IIQ), Departamento de Química Inorgánica and Centro de Innovación en Química Avanzada (ORFEO-CINQA), Consejo Superior de Investigaciones Científicas (CSIC) and University of Sevilla, 41092 Sevilla, Spain; o orcid.org/ 0000-0002-5155-1262; Email: jesus.campos@iiq.csic.es

\section{Authors}

Nereida Hidalgo - Instituto de Investigaciones Químicas (IIQ), Departamento de Química Inorgánica and Centro de Innovación en Química Avanzada (ORFEO-CINQA), Consejo Superior de Investigaciones Cientificas (CSIC) and University of Sevilla, 41092 Sevilla, Spain; 이이.org/ 0000-0001-6966-3556

Carlos Romero-Pérez - Instituto de Investigaciones Químicas (IIQ), Departamento de Química Inorgánica and Centro de Innovación en Química Avanzada (ORFEO-CINQA), Consejo Superior de Investigaciones Cientificas (CSIC) and University of Sevilla, 41092 Sevilla, Spain

Celia Maya - Instituto de Investigaciones Químicas (IIQ), Departamento de Química Inorgánica and Centro de Innovación en Química Avanzada (ORFEO-CINQA), Consejo Superior de Investigaciones Científicas (CSIC) and University of Sevilla, 41092 Sevilla, Spain

Israel Fernández - Departamento de Química Orgánica I and Centro de Innovación en Química Avanzada (ORFEO-CINQA), Facultad de Ciencias Químicas, Universidad Complutense de Madrid, Madrid 28040, Spain; (1) orcid.org/0000-0002-0186-9774

Complete contact information is available at: 
https://pubs.acs.org/10.1021/acs.organomet.1c00088

\section{Notes}

The authors declare no competing financial interest.

\section{ACKNOWLEDGMENTS}

This work was supported by the European Research Council (ERC Starting Grant, CoopCat, Project 756575) and the Spanish Ministry of Science and Innovation (Projects PID2019-110856GA-I00, PID2019-106184GB-I00, and RED2018-102387-T). We thank Dr. Rosie J. Somerville for helpful discussions.

\section{REFERENCES}

(1) (a) Campos, J. Bimetallic Cooperation Across the Periodic Table. Nat. Rev. Chem. 2020, 4, 696-702. (b) Farley, C. M.; Uyeda, C. Organic Reactions Enabled by Catalytically Active Metal-Metal Bonds. Trends Chem. 2019, 1, 497-509. (c) Berry, J. F.; Thomas, C. M. Multimetallic Complexes: Synthesis and Applications. Dalton Trans. 2017, 46, 5472-5473. (d) Berry, J. F.; Lu, C. C. Metal-Metal Bonds: From Fundamentals to Applications. Inorg. Chem. 2017, 56, 7577-7581. (e) Pye, D. R.; Mankad, N. P. Bimetallic Catalysis for $\mathrm{C}-\mathrm{C}$ and $\mathrm{C}-\mathrm{X}$ Coupling Reactions. Chem. Sci. 2017, 8, 1705-1718.

(2) Bauer, J.; Braunschweig, H.; Dewhurst, R. D. Metal-Only Lewis Pairs with Transition Metal Lewis Bases. Chem. Rev. 2012, 112, 4329-4346.

(3) (a) Álvarez, R.; De Lera, A. R.; Aurrecoechea, J. M.; Durana, A. Bimetallic Intermediates in the Formation of Nucleophilic Allenylzincs from Allenylpalladiums: A DFT Study. Organometallics 2007, 26, 2799-2802. (b) Fuentes, B.; García-Melchor, M.; Lledós, A.; Maseras, F.; Casares, J. A.; Ujaque, G.; Espinet, P. Palladium Round Trip in the Negishi Coupling of trans- $\left[\mathrm{PdMeCl}\left(\mathrm{PMePh}_{2}\right)_{2}\right]$ with ZnMeCl: An Experimental and DFT Study of the Transmetalation Step. Chem. - Eur. J. 2010, 16, 8596-8599. (c) Oeschger, R. J.; Chen, P. A Heterobimetallic Pd-Zn Complex: Study of a $\mathrm{d}^{8}-\mathrm{d}^{10}$ Bond in Solid State, in Solution, and in Silico. Organometallics 2017, 36, 1465-1468. (d) Paenurk, E.; Gershoni-Poranne, R.; Chen, P. Trends in Metallophilic Bonding in $\mathrm{Pd}-\mathrm{Zn}$ and $\mathrm{Pd}-\mathrm{Cu}$ Complexes. Organometallics 2017, 36, 4854-4863.

(4) (a) Casares, J. A.; Espinet, P.; Fuentes, B.; Salas, G. Insights into the Mechanism of the Negishi Reaction: $\mathrm{ZnRX}$ versus $\mathrm{ZnR}_{2}$ Reagents. J. Am. Chem. Soc. 2007, 129, 3508-3509. (b) delPozo, J.; Gioria, E.; Casares, J. A.; Álvarez, R.; Espinet, P. Organometallic Nucleophiles and Pd: What Makes $\mathrm{ZnMe}_{2}$ Different? Is Au Like $\mathrm{Zn}$ ? Organometallics 2015, 34, 3120-3128.

(5) (a) Liu, Q.; Lan, Y.; Liu, J.; Li, G.; Wu, Y.-D.; Lei, A. Revealing a Second Transmetalation Step in the Negishi Coupling and Its Competition with Reductive Elimination: Improvement in the Interpretation of the Mechanism of Biaryl Syntheses. J. Am. Chem. Soc. 2009, 131, 10201-10210. (b) van Asselt, R. V.; Elsevier, C. J. Rigid bidentate nitrogen ligands in organometallic chemistry and homogeneous catalysis. 8. On the Mechanism of Formation of Homocoupled Products in the Carbon-Carbon Cross-Coupling Reaction Catalyzed by Palladium Complexes Containing Rigid Bidentate Nitrogen Ligands: Evidence for the Exchange of Organic Groups between Palladium and the Transmetalating Reagent. Organometallics 1994, 13, 1972-1980.

(6) Liberman-Martin, A. L.; Levine, D. S.; Ziegler, M. S.; Bergman, R. G.; Tilley, T. D. Lewis Acid-Base Interactions Between Platinum(II) Diaryl Complexes and Bis(perfluorophenyl)zinc: Strongly Accelerated Reductive Elimination Induced by a Z-type Ligand. Chem. Commun. 2016, 52, 7039-7042.

(7) Miloserdov, F. M.; Rajabi, N. A.; Lowe, J. P.; Mahon, M. F.; Macgregor, S. A.; Whittlesey, M. K. Zn-Promoted C-H Reductive Elimination and $\mathrm{H}_{2}$ Activation via a Dual Unsaturated Heterobimetallic Ru-Zn Intermediate. J. Am. Chem. Soc. 2020, 142, 63406349.
(8) (a) Bajo, S.; Alférez, M. G.; Alcaide, M. M.; López-Serrano, J.; Campos, J. Metal-only Lewis Pairs of Rhodium with s, p and d-Block Metals. Chem. - Eur. J. 2020, 26, 16833-16845. (b) Lohrey, T. D.; Maron, L.; Bergman, R. G.; Arnold, J. Heterotetrametallic Re-Zn-ZnRe Complex Generated by an Anionic Rhenium(I) $\beta$ Diketiminate. J. Am. Chem. Soc. 2019, 141, 800-804. (c) Gair, J. J.; Qiu, Y.; Khade, R. L.; Chan, N. H.; Filatov, A. S.; Zhang, Y.; Lewis, J. C. Synthesis, Characterization, and Theoretical Investigation of a Transition State Analogue for Proton Transfer during C-H Activation by a RhodiumPincer Complex. Organometallics 2019, 38, 1407-1412. (d) Jayarathne, U.; Mazzacano, T. J.; Bagherzadeh, S.; Mankad, N. P. Heterobimetallic Complexes with Polar, Unsupported $\mathrm{Cu}-\mathrm{Fe}$ and $\mathrm{Zn}-\mathrm{Fe}$ Bonds Stabilized by N-Heterocyclic Carbenes. Organometallics 2013, 32, 3986-3992.

(9) For example: (a) Braunschweig, H.; Gruss, K.; Radacki, K. Complexes with Dative Bonds Between d- and s-Block Metals: Synthesis and Structure of $\left[\left(\mathrm{Cy}_{3} \mathrm{P}\right)_{2} \mathrm{Pt}-\mathrm{Be}(\mathrm{Cl}) \mathrm{X}\right](\mathrm{X}=\mathrm{Cl}, \mathrm{Me})$. Angew. Chem., Int. Ed. 2009, 48, 4239-4241. (b) Braunschweig, H.; Damme, A.; Dewhurst, R. D.; Hupp, F.; Jiménez-Halla, J. O. C.; Radacki, K. $\sigma$-Donor- $\sigma$-Acceptor Plumbylene Ligands: Synergic $\sigma$ Donation Between Ambiphilic Pt0 and PbII Fragments. Chem. Commun. 2012, 48, 10410-10412. (c) Braunschweig, H.; Gruss, K.; Radacki, K. Interaction between d- and p-Block Metals: Synthesis and Structure of Platinum-Alane Adducts. Angew. Chem., Int. Ed. 2007, 46, 7782-7784. (d) Bauer, J.; Braunschweig, H.; Damme, A.; Radacki, K. Reversible Insertion of Platinum into Coinage Group Metal-Halogen Bonds. Angew. Chem., Int. Ed. 2012, 51, 1003010033. (e) Schuster, J. K.; Muessig, J. H.; Dewhurst, R. D.; Braunschweig, H. Reactions of Digallanes with $\mathrm{p}$ - and d-Block Lewis Bases: Adducts, Bis(gallyl) Complexes, and Naked $\mathrm{Ga}^{+}$as Ligand. Chem. - Eur. J. 2018, 24, 9692-9697. (f) Bertermann, R.; Böhnke, J.; Braunschweig, H.; Dewhurst, R. D.; Kupfer, T.; Muessig, J. H.; Pentecost, L.; Radacki, K.; Sen, S. S.; Vargas, A. Dynamic, Reversible Oxidative Addition of Highly Polar Bonds to a Transition Metal. J. Am. Chem. Soc. 2016, 138, 16140-16147.

(10) Ma, M.; Sidiropoulos, A.; Ralte, L.; Stasch, A.; Jones, C. MetalOnly Lewis Pairs Featuring Unsupported $\mathrm{Pt} \rightarrow \mathrm{M}(\mathrm{M}=\mathrm{Zn}$ or $\mathrm{Cd})$ Dative Bonds. Chem. Commun. 2013, 49, 48-50.

(11) Jamali, S.; Abedanzadeh, S.; Khaledi, N. K.; Samouei, H.; Hendi, Z.; Zacchini, S.; Kia, R.; Shahsavari, H. R. A Cooperative Pathway for Water Activation Using a Bimetallic $\mathrm{Pt}^{0}-\mathrm{Cu}^{\mathrm{I}}$ system. Dalton Trans. 2016, 45, 17644-17651.

(12) Hidalgo, N.; Maya, C.; Campos, J. Cooperative Activation of $\mathrm{X}-\mathrm{H}(\mathrm{X}=\mathrm{H}, \mathrm{C}, \mathrm{O}, \mathrm{N})$ Bonds by a $\mathrm{Pt}(0) / \mathrm{Ag}(\mathrm{I})$ Metal-Only Lewis Pair. Chem. Commun. 2019, 55, 8812-8815.

(13) Resa, I.; Carmona, E.; Gutierrez-Puebla, E.; Monge, A. Decamethyldizincocene, a Stable Compound of $\mathrm{Zn}(\mathrm{I})$ with a $\mathrm{Zn}-\mathrm{Zn}$ Bond. Science 2004, 305, 1136-1138.

(14) Otsuka, S.; Yoshida, T.; Matsumoto, M.; Nakatsu, K. Bis(tertiary phosphine)palladium(0) and -Platinum(0) Complexes: Preparations and Crystal and Molecular Structures. J. Am. Chem. Soc. 1976, 98, 5850-5858.

(15) Sun, Y.; Piers, W. E.; Parvez, M. The Solid-State Structure of Bis(pentafluorophenyl)zinc. Can. J. Chem. 1998, 76, 513-517.

(16) Bollermann, T.; Gemel, C.; Fischer, R. A. Organozinc Ligands in Transition Metal Chemistry. Coord. Chem. Rev. 2012, 256, 537555.

(17) (a) Bollermann, T.; Freitag, K.; Gemel, C.; Seidel, R. D.; von Hopffgarten, M.; Frenking, G.; Fischer, R. A. The Reactivity of $\left[\mathrm{Zn}_{2} \mathrm{Cp}^{*}{ }_{2}\right]$ : Trapping Monovalent $\left\{\mathrm{ZnZnCp}^{*}\right\}$ in the Metal-Rich Compounds $\left[(\mathrm{Pd}, \mathrm{Pt})\left(\mathrm{GaCp}^{*}\right)_{\mathrm{a}}\left(\mathrm{ZnCp}^{*}\right)_{4-\mathrm{a}}\left(\mathrm{ZnZnCp}^{*}\right)_{4-\mathrm{a}}\right](\mathrm{a}=0,2)$. Angew. Chem., Int. Ed. 2011, 50, 772-776. (b) Cadenbach, T.; Bollermann, T.; Gemel, C.; Tombul, M.; Fernández, I.; Hopffgarten, M. V.; Frenking, G.; Fischer, R. A. Molecular Alloys, Linking Organometallics with Intermetallic Hume-Rothery Phases: The Highly Coordinated Transition Metal Compounds $\left[\mathrm{M}(\mathrm{ZnR})_{\mathrm{n}}\right](n$ $\geq 8$ ) Containing Organo-Zinc Ligands. J. Am. Chem. Soc. 2009, 131, 16063-16077. (c) Hornung, J.; Weßing, J.; Molon, M.; Dilchert, K.; Gemel, C.; Fischer, R. A. Chemistry of Hume-Rothery inspired 
organometallics: Selective functionalization of [M$\left.(\mathrm{ZnCp} *)_{4}\left(\mathrm{ZnCH}_{3}\right)_{4}\right](\mathrm{M}=\mathrm{Ni}, \mathrm{Pd}, \mathrm{Pt})$ with terminal alkynes to yield $\left[\mathrm{M}\left(\mathrm{ZnCp}^{*}\right)_{4}\left(\mathrm{ZnCCSi}{ }^{\mathrm{P} r}\right)_{4}\right]$. J. Organomet. Chem. 2018, 860, 78-84. (d) Bollermann, T.; Freitag, K.; Gemel, C.; Seidel, R. W.; Fischer, R. A. Reactivity of $\left[\mathrm{Zn}_{2} \mathrm{Cp}^{*}{ }_{2}\right]$ toward Transition-Metal Complexes: Synthesis and Characterization of $\left[\mathrm{Cp}^{*} \mathrm{M}\left(\mathrm{ZnCp}^{*}\right)_{3}\right](\mathrm{M}$ = Ni, Pd, Pt). Organometallics 2011, 30, 4123-4127. (e) Freitag, K.; Molon, M.; Jerabek, P.; Dilchert, K.; Rösler, C.; Seidel, R. W.; Gemel, C.; Frenking, G.; Fischer, R. A. Zn $\cdots$ Zn Interactions at Nickel and Palladium Centers. Chem. Sci. 2016, 7, 6413-6421.

(18) Cordero, B.; Gómez, V.; Platero-Prats, A. E.; Revés, M.; Echeverría, J.; Cremades, E.; Barragán, F.; Alvarez, S. Covalent radii revisited. Dalton Trans. 2008, 2832-2838.

(19) (a) Campos, C. Dihydrogen and Acetylene Activation by a Gold(I)/Platinum(0) Transition Metal Only Frustrated Lewis Pair. J. Am. Chem. Soc. 2017, 139, 2944-2947. (b) Hidalgo, N.; Moreno, J. J.; Pérez-Jiménez, M.; Maya, C.; López-Serrano, J.; Campos, J. Evidence for Genuine Bimetallic Frustrated Lewis Pair Activation of Dihydrogen with Gold(I)/Platinum(0) Systems. Chem. - Eur. J. 2020, 26, 5982-5993. (c) Hidalgo, N.; Moreno, J. J.; Pérez-Jiménez, M.; Maya, C.; López-Serrano, J.; Campos, J. Tuning Activity and Selectivity during Alkyne Activation by Gold(I)/Platinum(0) Frustrated Lewis Pairs. Organometallics 2020, 39 (13), 2534-2544.

(20) Goel, R. G.; Ogini, W. O.; Srivastava, R. C. Preparation, Characterization and Some Reactions of Bis(tri-tert-butylphosphine)hydridoplatinum(II) Complexes. Organometallics 1982, 1, 819-824.

(21) Werkmeister, S.; Fleischer, S.; Zhou, S.; Junge, K.; Beller, M. Development of New Hydrogenations of Imines and Benign Reductive Hydroaminations: Zinc Triflate as a Catalyst. ChemSusChem 2012, 5, 777-782.

(22) Pandolfo, L.; Maggini, M. Reaction of trans- $\left[\mathrm{Pt}(\mathrm{H})_{2}\left(\mathrm{PCy}_{3}\right)_{2}\right]$ with $\mathrm{C}_{60}$ reductive elimination of $\mathrm{H}_{2}$ and formation of $\left[\mathrm{Pt}\left(\mathrm{PCy}_{3}\right)_{2}\left(\eta^{2}\right.\right.$ $\left.\mathrm{C}_{60}\right)$ ]. J. Organomet. Chem. 1997, 540, 61-65.

(23) (a) Skara, G.; De Vleeschouwer, F.; Geerlings, P.; De Proft, F.; Pinter, B. Heterolytic Splitting of Molecular Hydrogen by Frustrated and Classical Lewis Pairs: A Unified Reactivity Concept. Sci. Rep. 2017, 7, 16024. (b) Daru, J.; Bakó, I.; Stirling, A.; Pápai, I. Mechanism of Heterolytic Hydrogen Splitting by Frustrated Lewis Pairs: Comparison of Static and Dynamic Models. ACS Catal. 2019, 9, 6049-6057. (c) Yepes, D.; Jaque, P.; Fernández, I. Deeper Insight into the Factors Controlling $\mathrm{H}_{2}$ Activation by Geminal AminoboraneBased Frustrated Lewis Pairs. Chem. - Eur. J. 2016, 22, 18801-18809. (d) Liu, L.; Cao, L. L.; Shao, Y.; Ménard, G.; Stephan, D. W. A Radical Mechanism for Frustrated Lewis Pair Reactivity. Chem. 2017, 3, 259-267. (e) Hamilton, H. B.; Wass, D. F. How Important Are Radical Mechanisms in Frustrated Lewis Pair Chemistry? Chem. 2017, 3, 198-210.

(24) (a) Dobrovetsky, R.; Stephan, D. W. $t \mathrm{Bu}_{3} \mathrm{P} / \mathrm{ZnR}_{2}$ (R = Et, I) Frustrated Lewis Pair Catalysts for Functionalization and Reduction of $\mathrm{CO}_{2}$. Isr. J. Chem. 2015, 55, 206-209. (b) Jochmann, P.; Stephan, D. W. $\mathrm{H}_{2}$ Cleavage, Hydride Formation, and Catalytic Hydrogenation of Imines with Zinc Complexes of $\mathrm{C}_{5} \mathrm{Me}_{5}$ and N-Heterocyclic Carbenes. Angew. Chem., Int. Ed. 2013, 52, 9831-9835.

(25) Zhang, Y.; Karunananda, M. K.; Yu, H.-C.; Clark, K. J.; Williams, W.; Mankad, N. P.; Ess, D. H. Dynamically Bifurcating Hydride Transfer Mechanism and Origin of Inverse Isotope Effect for Heterodinuclear AgRu-Catalyzed Alkyne Semihydrogenation. ACS Catal. 2019, 9, 2657-2663.

(26) Nisa, R. U.; Ayub, K. Mechanism of $\mathrm{Zn}(\mathrm{OTf})_{2}$ Catalyzed Hydroamination-Hydrogenation of Alkynes with Amines: Insight from Theory. New J. Chem. 2017, 41, 5082-5090.

(27) Jaw, H.-R. C.; Mason, W. R. Electronic Absorption and MCD Spectra for Isoelectronic Linear Two-Coordinate Bis(tri-tert-butylphosphine)metal Complexes of Platinum(0) and Gold(I). Inorg. Chem. 1989, 28, 4370-4373.

(28) Fleckenstein, J. E.; Koszinowski, K. Lithium Organozincate Complexes LiRZnX $\mathrm{X}_{2}$ : Common Species in Organozinc Chemistry. Organometallics 2011, 30, 5018-5026.
(29) Pentamethylcyclopentadienyl zinc(I) dimer, $\left\{\mathrm{Zn}\left(\eta^{5}-\mathrm{C}_{5} \mathrm{Me}_{5}\right)\right\}_{2}$ : Peloso, R.; Resa, I.; Rodríguez, A.; Carmona, E.; Freitag, K.; Jones, C.; Stasch, A.; Boutland, A. J.; Lips, F. Pentamethylcyclopentadienyl Zinc(I) dimer, $\left\{\mathrm{Zn}\left(\eta^{5}-\mathrm{C}_{5} \mathrm{Me}_{5}\right)\right\}_{2}$. Inorg. Synth. 2018, 37, 33-45.

(30) Goel, R. G.; Ogini, W. O.; Srivastava, R. C. Preparation, Characterization and Some Reactions of Bis(tri-tert-butylphosphine)hydridoplatinum(II) Complexes. Organometallics 1982, 1, 819-824. 